\title{
Medicine use evaluation in a psychosocial support center in a city of Pernambuco
}

\begin{abstract}
Thaís Araújo de SANTANA ${ }^{1}\left(\mathbb{D}^{2}\right.$, Apache Santiago FERREIRA ${ }^{1}(\mathbb{D})$, Sheila Elcielle ARRUDA ${ }^{1}$, Aline Silva FERREIRA ${ }^{1}$, Emerson de Oliveira SILVA ${ }^{1}$, Matheus Alves ANGELOS ${ }^{1}$, Pedro Rolim NETO ${ }^{1}$ (D), Rosali Maria da SILVA ${ }^{1}$
\end{abstract}

Filiação: ${ }^{1}$ Departamento de Ciências Famacêuticas, UFPE. Recife, PE, Brasil.

Corresponding author: Silva RM, rosaliltm@gmail.com

Submitted: 28-04-2019 Resubmitted: 04-06-2020 Accepted: 04-07-2020

Peer review: blind reviewers

\begin{abstract}
Objective: The objective of this study is to evaluate the profile of medicine usage in a Psychosocial Support Center type II (PSC), in the city of Jaboatão dos Guararapes-PE, Brazil. Methods: This is a retrospective cross-sectional descriptive study with a quantitative approach. The information obtained for the study came from the analysis of medical records of patients admitted to the institution from January to August 2015. A total of 157 medical records were analyzed, observing to sociodemographic, clinical and medication use variables. Results: There was a predominance of female patients, 57.25\% (male 42.75\%). Most of the participants were single, with incomplete elementary education, aged between 30-39 years. Most of them had previously been admitted to psychiatric hospitals. From the total number of users who reached the PSC, 60.5\% were referred by the Psychosocial Care Network. The most frequent diagnoses, according to the International Statistical Classification of Diseases and Related Health Problems (ICD), were: schizophrenia, schizotypic disorders and delusional disorders (F20 to F29), and affective mood disorders (F30-F39). It was found that 99.4\% of patients used at least 1 medication, which was used twice daily (59.6\%). The most prescribed class of drugs was the antipsychotics, mainly chlorpromazine, haloperidol and risperidone. From the total prescribed drugs, $83.3 \%$ were in accordance with the Brazilian Common Denomination $85 \%$ of them were present in the municipal list of essential drugs and $97 \%$ were administered orally. Conclusion: The results found in this study were satisfactory. Thus, it was possible to verify that the medicines are great allies in the psychosocial treatment, presenting as a widely-used resource.
\end{abstract}

Keywords: drug utilization, psychotropic drugs, mental health, drug prescriptions.

\section{Avaliação do uso de medicamentos em centro de suporte psicossocial em um município de Pernambuco}

\begin{abstract}
Resumo
Objetivo: O objetivo desse estudo consiste em avaliar o perfil do uso de medicamentos em um Centro de Apoio Psicossocial tipo II (CAPS), no município de Jaboatão dos Guararapes-PE, Brasil. Métodos: Trata-se de um estudo descritivo retrospectivo, transversal, com abordagem quantitativa. As informações obtidas para o estudo vieram da análise de prontuários dos pacientes internados na instituição, no período de janeiro a agosto de 2015. Foram analisados 157 prontuários, observando às variáveis sociodemográficas, clínicas e uso de medicamentos. Resultados: Houve predomínio de pacientes do sexo feminino, 57,25\% (sexo masculino 42,75\%). A maioria dos participantes eram solteiros, com ensino fundamental incompleto, idade entre 30-39 anos. Maior parte deles já havia sido internado em hospitais psiquiátricos. Do total de usuários que alcançaram o CAPS, 60,5\% foram encaminhados pela Rede de Atenção Psicossocial. Os diagnósticos mais frequentes, segundo a código internacional de doenças, foram: esquizofrenia, distúrbios esquizotípicos e transtornos delirantes (F20 a F29) e transtornos afetivos de humor (F30-F39). Verificou-se que 99,4\% dos usuários faziam uso de pelo menos 1 medicamento, sendo mais comum a utilização duas vezes ao dia $(59,6 \%)$ e a classe mais prescrita era a dos antipsicóticos, principalmente, clorpromazina, haloperidol e risperidona. Do total de medicamentos prescritos 83,3\% foi de acordo com a Denominação Comum Brasileira, $85 \%$ deles estavam presentes na relação municipal de medicamentos essenciais e $97 \%$ foram administrados por via oral. Conclusão: Os resultados encontrados neste estudo foram satisfatórios, podendo ser confirmado que os medicamentos são grandes aliados no tratamento psicossocial, apresentando-se como um recurso amplamente utilizado.
\end{abstract}

Palavras-chave: utilização de medicamentos, drogas psicotrópicas, saúde mental, prescrições de medicamentos. 


\section{Introduction}

The treatment of people with mental disorders in Brazil, in the 19th and early 20th centuries, consisted mainly of hospitalizations in nursing homes and psychiatric hospitals ${ }^{1}$. The nature of the treatments in these institutions was punitive, totalitarian, excluding, and caused an aggravation of the psychic suffering, making difficult the insertion of the individual in society ${ }^{2}$. A series of events contributed to what was called psychiatric reform. In Brazil, this movement advocated the decentralization of psychiatric hospitals, the reduction of hospital beds and the adoption of a more communitarian treatment model ${ }^{2}$.

It is known that mental disorders affect about seven hundred thousand people in the world. Estimates from the World Health Organization (WHO) show that one in four people in the world should develop some type of mental disorder throughout their lifetime $^{3}$. Thus, the Psychosocial Support Centers (PSC) play an important role in the new scenario of mental health practices. The purpose of these units is to provide clinical care to the population and ensure the social reintegration of users to the community4.

As for the demand, PSC can be classified in Psychosocial Support Centers for children and teenagers (PSCCT) and Psychosocial Alcohol and Drug Support Centers (PADSC). They can also be classified according to the size of the institution and staff PSCS type I (city with 20,000 and 70,000 inhabitants), II (city with 70,000 and 200,000 inhabitants) and III (city with more than 200,000 inhabitants) ${ }^{5}$.

Type II PSCS provides daily care to adults, in their population covered, with severe and persistent mental disorders in which the use of alcohol and other drugs is secondary to the clinical condition of mental disorder. Providing assistance in the form of individual, group and therapeutic workshops, carrying out home visits, family care and community activities for patient integration. In addition, they provide patients assisted in one shift with one daily meal and those assisted in two shifts with two daily meals ${ }^{5}$.

Since 1952, psychopharmacology has been playing an important role in treating people with mental disorders, an efficient resource for the reduction and duration of psychiatric hospitalizations ${ }^{2,6}$ The use of psychoactive drugs in mental health has gained space in such a way that it is an indispensable tool nowadays ${ }^{7}$. When in combination with non-pharmacological treatments, the rational use of these medicines allows the control and reduction of symptoms and, in addition, favors the insertion of the individual into society ${ }^{8}$.

However, despite the benefits they bring, psychoactive drugs are often associated with episodes of tolerance, addiction and serious interactions with substances such as alcohol. The inadequate use of these drugs can also lead to an increase in public fund spending, with consequent reduction of access ${ }^{9,10}$.

Medicine usage studies are important tools to establish estimates of the effectiveness, safety and costs of the drugs used, as well as to assess the quality of prescriptions and drug procurement processes ${ }^{11}$. Studies such as the one carried out by Souza and collaborators $(2012)^{12}$, emphasize the need for follow-up of the pharmacotherapy of patients with mental disorders, since these patients are polymedicated, and the psychoactive drugs cause adverse effects that can interfere with patient compliance.

Considering that drug therapy is an important ally in psychosocial treatment, it is indispensable to know the profile of the use of psychoactive drugs, in order to minimize possible aggravations resulting from the incorrect use of these drugs, so that improvements can be achieved at the institution. Thus, this study was performed in a PSC type II located in the city of Jaboatão dos
Guararapes-PE, Brazil. The institution offers daily care to adults with severe and persistent mental disorders.

\section{Methods}

A retrospective, cross-sectional, descriptive study with a quantitative that was carried out at a Psychosocial Care Center type II, located in the neighborhood of Prazeres, in the city of Jaboatão dos Guararapes-PE, Brazil. This PSC was founded in 2003, being the first in the city, receives daily patients with severe and persistent psychic disorders. The unit counts on an interdisciplinary team, composed of occupational therapists, nurses, pharmacists, psychologists, psychiatrists and social workers.

The data required for the research were gathered from the analysis of multiprofessional medical records of patients who entered the PSC from January to August 2015 as an inclusion criterion. Medical records that did not fit the specified study period were excluded.

Based on the admissions book, available in the unit, there were 180 medical records of patients in the period delimited by the study, sampling was carried out from this population, using the formula presented in the study by Miot $(2011)^{13}$ to calculate the minimum sample needed. The confidence level adopted was 95\%, the standard error was $5 \%$, the proportion of favorable and unfavorable results in the population was also $5 \%$. And a value of $30 \%$ was added to the sample size to guarantee cases of loss (secondary data) in some study variables in order to make the statistical analysis feasible within the pre-established reliability assumptions ${ }^{13}$.

From that point on, sampling was defined in a non-random manner. The parameter used for insertion into the sample was the patient's month of admission to the service, from which the entire sample was determined consecutively as established in the inclusion criteria of this work. Considering that there was no direct interaction with the research subjects, but the collection of secondary data, the recruitment of patients was carried out through an active search in the unit's admission book and the review of the medical records of patients.

In the admission book, information was obtained on the date of entry of users into the unit and referral source of the users. Then, the medical records of each user were observed. It was collected information regarding the socio-demographic, clinical and medicines use. The sociodemographic variables analyzed were: gender, age, civil status, educational level and occupation. As for the clinical profile, the diagnosis of the patients, according to the tenth version of the international code of diseases (ICD-10), history of hospitalizations, use of psychoactive substances and comorbidities were observed.

Dosage, route of administration, frequency of use, percentage of prescription drugs based on the Municipal Relation of Essential Drugs (MRED), drugs prescribed by the Brazilian Common Denomination $(B C D)$, and quantity of drugs prescribed for each user.

The statistical analysis of the data was performed in Microsoft Excel $^{\circ}$ (Microsoft Office 2007), observing the absolute frequency and percentage of variables, in addition to standard deviation (SD). $T$ test and Chi-square to compare proportions in some cases. The level of significance adopted in all analyses was of $5 \%(p \leq 0.05)$. The drugs were classified according to the Anatomical Therapeutic Chemical (ATC) classification system.

The project was approved by the Research Ethics Committee of the Federal University of Pernambuco, and followed the guidelines of resolution $466 / 12$ by the National Health Council (NHC). It was approved for evaluation with the document number CAAE:45354415.3.0000.5208. 


\section{Results}

In the study, a total of 157 medical records were analyzed. Of these, $57.25 \%(n=90)$ referred to female users and $42.75 \%(n=67)$ to male users. Regarding the age of the institution's users, the average was 38.5 years. The highest number were individuals aged 30 to 39 years, whose percentage was $30.6 \%(n=48)$, as shown in Table 1. Among the medical records observed, the majority refers to single users (62.4\%), with incomplete elementary education
(29.9\%) (Table 1). It was also verified that about $28.7 \%(n=45)$ of the users do not have any occupation or professional activity, and of those who do, $16.6 \%$ are housewives (Table 1 ).

Among the medical records observed, $49.0 \%$ referred to users who had already had psychiatric hospitalizations, another $45.0 \%$ had never been hospitalized in psychiatric hospitals until the date of the study and $6.0 \%$ did not report it. Regarding the number of hospitalizations, 19.8\% had an admission; $7.1 \%$ had two and $5.7 \%$ more than ten hospitalizations.

Table 1. Characterization of the sociodemographic variables (degree of education, occupation, civil status) and distribution of diagnostic hypothesis of the patients, according to ICD-10.

\begin{tabular}{|c|c|c|c|c|}
\hline Information & $\begin{array}{l}\text { All patients } \\
(\mathrm{N}=157) \mathrm{n}(\%)\end{array}$ & $\begin{array}{l}\text { Female } \\
\mathrm{n}(\%)\end{array}$ & $\begin{array}{l}\text { Male } \\
\mathrm{n}(\%)\end{array}$ & $P$ value \\
\hline Age (years) Mean $\pm S D$ & $38.5 \pm 18.6$ & & & \\
\hline \multicolumn{5}{|l|}{ Range $\mathrm{n}(\%)$} \\
\hline $17-19$ & $5(3.2)$ & $3(1.9)$ & $2(1.3)$ & $*^{*} 0,5267$ \\
\hline $20-29$ & $45(28.7)$ & $22(14)$ & $23(14.7)$ & \\
\hline 30-39 & $48(30.6)$ & $27(17.2)$ & $21(13.4)$ & \\
\hline $40-49$ & $25(15.9)$ & $15(9.5)$ & $10(6.4)$ & \\
\hline $50-59$ & $23(14.6)$ & $15(9.5)$ & $8(5.1)$ & \\
\hline$>=60$ & $9(5.7)$ & $7(4.5)$ & $2(1.2)$ & \\
\hline Not informed & $2(1.3)$ & $1(0.65)$ & $1(0.65)$ & \\
\hline \multicolumn{5}{|l|}{ Degree of education } \\
\hline No education at all & $8(5.1)$ & $5(3.2)$ & $3(1.9)$ & $* 0,5366$ \\
\hline Incomplete primary school & $47(29.9)$ & $19(12.1)$ & $28(17.8)$ & \\
\hline Complete primary school & $13(8.3)$ & $7(4.5)$ & $6(3.8)$ & \\
\hline Incomplete secondary school & $11(7.0)$ & $6(3.8)$ & $5(3.2)$ & \\
\hline Complete secondary school & $26(16.6)$ & $17(10.8)$ & $9(5.7)$ & \\
\hline Undergraduate & $8(5.1)$ & $7(4.5)$ & $1(0,6)$ & \\
\hline Graduate & $2(1.3)$ & $1(0.6)$ & $1(0,6)$ & \\
\hline Not informed & $42(26.7)$ & $28(17.8)$ & $14(8.9)$ & \\
\hline \multicolumn{5}{|l|}{ Civil status } \\
\hline Single & $98(62.4)$ & $47(29.9)$ & $51(32.5)$ & $* 0,7347$ \\
\hline Married & $43(27.4)$ & $28(17.8)$ & $15(9.6)$ & \\
\hline Widow & $1(0.6)$ & $1(0.6)$ & & \\
\hline Divorced & $3(2.0)$ & $3(1.9)$ & & \\
\hline Not informed & $12(7.6)$ & $11(7)$ & $1(0.6)$ & \\
\hline \multicolumn{5}{|l|}{ Occupation } \\
\hline Retired & $4(2.5)$ & $3(1.9)$ & $10.6)$ & $* 0,5575$ \\
\hline Autonomous & $3(1.9)$ & $2(1.3)$ & $1(0.6)$ & \\
\hline Hairdresser & $3(1.9)$ & $1(0.6)$ & $2(1.3)$ & \\
\hline House wife & $26(16.6)$ & $25(15.9)$ & $1(0.6)$ & \\
\hline Student & $9(5.7)$ & $4(2.5)$ & $5(3.2)$ & \\
\hline Bricklayer/Bricklayer assistant & $7(4.5)$ & & $7(4.5)$ & \\
\hline Teacher & $3(1.9)$ & $2(1.3)$ & $1(0.6)$ & \\
\hline Seller & $4(2.5)$ & $1(0.6)$ & $3(1.9)$ & \\
\hline$* * *$ Others & $27(17.2)$ & $15(9.5)$ & $12(7.7)$ & \\
\hline None & $45(28.7)$ & $21(13.4)$ & $24(15.3)$ & \\
\hline Not informed & $26(16.6)$ & $16(10.2)$ & $10(6.4)$ & \\
\hline \multicolumn{5}{|l|}{ ICD-10 } \\
\hline Organic Mental Disorders (F00-F09) & $6(3.8)$ & $3(1.9)$ & $3(1.9)$ & $* * 0,0049$ \\
\hline Mental and behavioral disorders due to the use of psychoactive substances (F10-F19) & $2(1.3)$ & & $2(1.3)$ & \\
\hline Schizophrenia, schizotypal disorders and delusional disorders (F20-F29) & $64(40.8)$ & $28(17.8)$ & $36(22.9)$ & \\
\hline Affective Mood Disorders (F30-F39) & $38(24.2)$ & $27(17.2)$ & $11(7.0)$ & \\
\hline Neurotic disorders, disorders related to stress and somatoform disorders (F40-F48) & $6(3.8)$ & $6(3.8)$ & & \\
\hline $\begin{array}{l}\text { Behavioral syndromes associated with physiological dysfunctions and physical factors } \\
\text { (F50-F59) }\end{array}$ & $1(0.6)$ & $1(0.6)$ & & \\
\hline Mental retardation (F70-F79) & $4(2.6)$ & $2(1.3)$ & $2(1.3)$ & \\
\hline More than one diagnostic & $28(17.8)$ & $15(9.6)$ & $13(8.3)$ & \\
\hline Not informed & $8(5.1)$ & $8(5.1)$ & & \\
\hline
\end{tabular}


The total number of users who reached the PSC sent by Networks of Psychosocial Attention (NPA) members was 60.5\% (95 patients). Among these services, the psychiatric hospitals were responsible for $43.3 \%$ of referrals, and about $26.8 \%$ of users reached the PSC by spontaneous demand.

Regarding the diagnosis, the highest percentage was of users diagnosed with schizophrenia, schizotypal disorders and delusional disorders, group F20 to F29 according to ICD-10, corresponding to $40.8 \%$ ( $n=64$ ) of the patients. Another $24.2 \%$ of the users were diagnosed with affective mood disorders (group F30 to F39) and $17.8 \%$ presented more than one diagnosis (Table 1). In the correlation between diagnosis and gender, women, besides schizophrenia and schizotypal and delusional disorders, had a higher percentage of affective mood disorders.

Moreover, according to the medical records analyzed, 59.2\% of users did not use or never used psychoactive substances such as alcohol, tobacco, cocaine and marijuana. Another $20.4 \%$, do or have already made use of some kind of psychoactive substance. And the rest $20.4 \%$ did not remember or did not report. Regarding the occurrence of comorbidities, in $59.9 \%$ of the medical records, there were no reports of clinical pathologies associated with mental disorders. Another 15.9\% reported clinical pathologies, of which $3.8 \%$ had hypertension and $2.6 \%$ had allergic problems, among others.

From the analysis of the medical records, it was quantified that 533 drugs were prescribed, which gives an average of about 3.39 drugs per patient $(n=157)$. It was possible to observe that for 99.4\% ( $n=156$ ) of PSC users, at least one drug was prescribed. For only $0.6 \%(n=1)$, there were no prescription drugs. It was also observed that the maximum number of drugs prescribed was six and the minimum amount of one drug. As for the frequency of drug use, it was observed that $59.6 \%$ of users used drugs twice daily, $23.7 \%$ once daily and $16.7 \%$ three times daily.

Of the total medications, $83.3 \%(n=444)$ were prescribed by the $\mathrm{BCD}$ (Table 2), the commercial names most used in the prescriptions were Haldol ${ }^{\circ}$, Amplictil ${ }^{\circ}$ and Depakene ${ }^{\circ}$. It was also observed that $85.0 \%(n=453)$ of prescribed medications were present in the MRED of Jaboatão dos Guararapes-PE, Brazil (Table 2). The drugs that were not present in MRED accounted for $15.0 \%$ of the total prescribed drugs: bromazepam, estazolam, levomepromazine,

Table 2. Description of drugs prescribed according to the ATC classification (prescribed doses, route of administration) and distribution according to BCD or trade name, inclusion in MRED.

\begin{tabular}{|c|c|c|c|c|c|c|c|}
\hline \multirow{2}{*}{ Classification (ATC) } & \multirow{2}{*}{$\begin{array}{l}\text { All } \\
N=533 \\
n(\%)\end{array}$} & \multicolumn{2}{|c|}{ Description of the medicine } & \multicolumn{2}{|c|}{$\begin{array}{l}\text { MRED constant } \\
\text { medication }\end{array}$} & \multicolumn{2}{|c|}{ Route of administration } \\
\hline & & $\begin{array}{l}\text { According to BCD } \\
\mathrm{n}(\%)\end{array}$ & $\begin{array}{l}\text { Commercial name } \\
\text { n (\%) }\end{array}$ & $\begin{array}{l}\text { Yes } \\
\text { n (\%) }\end{array}$ & $\begin{array}{l}\text { No } \\
\mathrm{n}(\%)\end{array}$ & $\begin{array}{l}\text { Oral route } \\
\mathrm{n}(\%)\end{array}$ & $\begin{array}{l}\text { Other routes } \\
\mathrm{n}(\%)\end{array}$ \\
\hline \multicolumn{8}{|l|}{ Antiepileptics } \\
\hline Valproic acid 250 e 500 mg (N03AG0) & $47(8.8)$ & $31(5.8)$ & $16(3.0)$ & $47(8.8)$ & & $47(8.8)$ & \\
\hline Carbamazepine 100 e 200 mg (N03AF01) & $13(2.4)$ & $13(2.4)$ & & $13(2.4)$ & & $13(2.4)$ & \\
\hline Clonazepam 2 e 10 mg (N03AE01) & $43(8.1)$ & $41(7.7)$ & $2(0.4)$ & $43(8.1)$ & & $43(8.1)$ & \\
\hline Phenobarbital 100 mg (N03AA02) & $3(0.6)$ & $3(0.6)$ & & $3(0.6)$ & & $3(0.6)$ & \\
\hline Topiramate 25 mg (N03AX11) & $1(0.2)$ & $1(0.2)$ & & & $1(0.2)$ & $1(0.2)$ & \\
\hline \multicolumn{8}{|l|}{ Anticholinergics } \\
\hline Biperidene 2 mg (N04AA02) & $56(10.5)$ & $50(9.4)$ & $6(1,1)$ & $56(10.5)$ & & $56(10.5)$ & \\
\hline \multicolumn{8}{|l|}{ Antipsychotics } \\
\hline Lithium carbonate 300 mg (N05AN01) & $11(2.1)$ & $11(2.1)$ & & $11(2.1)$ & & $11(2.1)$ & \\
\hline Chlorpromazine 25 e 100 mg (N05AA01) & $65(12.2)$ & $48(9.0)$ & $17(3.2)$ & $65(12.2)$ & & $65(12.2)$ & \\
\hline Fluphenazine $25 \mathrm{mg} / \mathrm{ml}$ (N05AB02) & $8(1.5)$ & $8(1.5)$ & & $8(1.5)$ & & & $8(1.5)$ \\
\hline $\begin{array}{l}\text { Haloperidol and decanoate of Haloperidol 5, } \\
25 \mathrm{mg} \text { e } 50 \mathrm{mg} / \mathrm{ml} \text { (N05AD01) }\end{array}$ & $62(11.6)$ & $27(5.0)$ & $35(6.6)$ & $62(11.6)$ & & $54(10.1)$ & $8(1.5)$ \\
\hline Risperidone 1, 2 e 3 mg (N05AX08) & $58(10.9)$ & $58(10.9)$ & & & $58(10.9)$ & $58(10.9)$ & \\
\hline Levomepromazine 25 e 100 mg (N05AA02) & $9(1.7)$ & $1(0.2)$ & $8(1.5)$ & & $9(1.7)$ & $9(1.7)$ & \\
\hline Olanzapine 2,5, 5 e 10 mg (N05AH03) & $7(1.3)$ & $7(1.3)$ & & & $7(1.3)$ & $7(1.3)$ & \\
\hline Thioridazine 50 mg (N05AC02) & $1(0.2)$ & & $1(0.2)$ & & $1(0.2)$ & $1(0.2)$ & \\
\hline \multicolumn{8}{|l|}{ Anxiolytics } \\
\hline Bromazepam 6 mg (N05BA08) & $1(0.2)$ & $1(0.2)$ & & & $1(0.2)$ & $1(0.2)$ & \\
\hline Diazepam 5 e 10 mg (N05BA01) & $30(5.6)$ & $30(5.6)$ & & $30(5.6)$ & & $30(5.6)$ & \\
\hline \multicolumn{8}{|l|}{ Hypnotics and sedatives } \\
\hline Estazolam 2 mg (N05CD04) & $1(0.2)$ & & $1(0.2)$ & & $1(0.2)$ & $1(0.2)$ & \\
\hline \multicolumn{8}{|l|}{ Antidepressants } \\
\hline Amitriptyline 25 mg (N06AA09) & $25(4.7)$ & $25(4.7)$ & & $25(4.7)$ & & $25(4.7)$ & \\
\hline Fluoxetine 20 mg (N06AB03) & $33(6.2)$ & $33(6.2)$ & & $33(6.2)$ & & $33(6.2)$ & \\
\hline Sertraline 50 mg (N06AB06) & $1(0.2)$ & $1(0.2)$ & & & $1(0.2)$ & $1(0.2)$ & \\
\hline Venlafaxine 150 mg (N06AX16) & $1(0.2)$ & $1(0.2)$ & & & $1(0.2)$ & $1(0.2)$ & \\
\hline \multicolumn{8}{|l|}{ Antihistamine for systemic use } \\
\hline Promethazine 25 mg (R06AD02) & $57(10.6)$ & $54(10.0)$ & $3(0.6)$ & $57(10.6)$ & & $57(10.6)$ & \\
\hline
\end{tabular}


olanzapine, risperidone, sertraline, thioridazine, topiramate and venlafaxine. It was also observed that $97.4 \%(n=519)$ of the drugs were included in National Relation of Essential Drugs (NRED). Only $2.6 \%(n=14)$ were not on any of the essential drug lists (MRED and NRED).

Regarding the route of administration, only $3.0 \%$ of the prescribed drugs were injectable; those being: Fluphenazine and Decanoate of Haloperidol. The other drugs, $97.0 \%(n=517)$ were orally administered. It was also observed that there was a solicitation for partitioning of the tablets in $1.3 \%$ of prescribed drugs. These drugs were Chlorpromazine100 mg, Clonazepam 2 mg, Risperidone 3 $\mathrm{mg}$ and Haloperidol $5 \mathrm{mg}$.

The most commonly prescribed medications were Chlorpromazine $12.2 \%(n=64)$, Haloperidol $11.6 \%(n=62)$, Risperidone $10.9 \%$ $(n=58)$, Promethazine $10.7 \%(n=57)$, Biperidene $10.5 \%(n=56)$ and Valproic acid $8.8 \%(n=47)$, as shown in Table 2 .

\section{Discussion}

In the analysis of the demographic profile of the patients who had their medical records analyzed, some data were observed: gender, age, degree of education, civil status and occupation (Table 1). Of the 157 medical records evaluated, 90 of these were female and 67 males. Other works carried out in PSCs such as Paula (2007), Kantorski and collaborators (2011) and Oliveira and collaborators (2014) also showed a higher percentage of female users, corroborating the findings of this study ${ }^{14-16}$.

Regarding the age of the users of the institution, the study presented similar results to the ones of Oliveira and collaborators $(2014)^{16}$, where the average age was 38,5 years and the most prevalent age group was also from 30 to 39 years. Regarding civil status and degree of education, it was observed that most of the records refer to single users and the ones with incomplete elementary school, these results corroborate those of Paula $(2007)^{14}$, In addition, as in the study conducted by Freitas and Souza $(2010)^{17}$ in a PSC of the city of Ilhéus-BA, Brazil, $53.4 \%$ of the users had some kind of occupation, being $21.0 \%$ of them housewives.

In the evaluation of the clinical profile, the results showed that $49 \%$ of the patients had psychiatric hospitalizations and $45 \%$ were never admitted to psychiatric hospitals, compared to those found in the work of Paula (2007) ${ }^{14}$, where $43 \%$ of sick patients were admitted to psychiatric hospitals and $57 \%$ never were. These data emphasize the importance of the PSC in the reintegration of these individuals into society ${ }^{18}$. As for the forms of referral, the results confirmed by Ballarin and collaborators $(2011)^{19}$ and Mangualde and collaborators $(2013)^{20}$, where the majority of users were also referred to health services or that indicates the effectiveness of the health care network in the city, considering the total number of references of NPAS units that exceeded the spontaneous demand for the service.

According to the administrative rule No. 1,077 of August 24th, 1999, the knowledge about the most frequent pathologies in mental health services is necessary for the acquisition of financial resources and for establishing the rational use of psychoactive drugs $^{21}$. The work by Ballarin and collaborators $(2011)^{19}$ and Freitas and Souza (2010) ${ }^{17}$ also presented a prevalence of F20 to F29 disorders, followed by affective mood disorders (F30 to F39) in all the studied PSC (Table 1). As women were responsible for the highest percentage of schizophrenia, schizotypal and delusional disorders, and affective mood disorders ( $p \leq 0.05)$, similar to those described by Oliveira and collaborators $(2014)^{16}$.

Women generally have a greater tendency to develop depressive and anxious disorders, especially during reproductive periods ${ }^{22}$. In addition, the multiple role of women in society, their insertion in the labor market, household chores, family care, are factors that can be responsible for the higher prevalence of mental health problems observed in the female population ${ }^{23}$.

Some studies report the frequent relationship between psychoactive substance usage and mental disorders ${ }^{24-25}$. The use of these substances significantly interferes in the treatment of these patients, which may impair patient compliance, causing a worsening of the clinical case, an increase in the occurrence of seizures and passage through emergency services ${ }^{25}$.

Regarding the institution's drug profile, the results clearly showed the expressive use of drugs by the patients of this PSC. These data also demonstrate that medicines have become key players in the treatment of mental disorders and highlights the need to know and analyze their usage profile. A similar result was also reported by Kantorski and collaborators $(2011)^{15}$, where $91.8 \%$ of PSC users included in the study used medications. In recent years, there has been an increase in the pattern of usage of psychoactive drugs and its prevalence in psychosocial care services. This scenario can be justified by the emergence of new drugs and an increase in the diagnosis of mental disorders ${ }^{26}$.

Some authors, such as Ferrazza and collaborators $(2013)^{27}$ and Xavier and collaborators $(2014)^{28}$ criticize the adoption of pharmacological treatment as a principle in therapy of patients with mental disorders, advocating the adoption of other tools, so that the medication is used as a last alternative. In fact, the indiscriminate use of medications involves problems. Excessive prescription of medications increases public expenditures with drugs, leading to the occurrence of drug interactions and side effects $^{29}$.In addition, the banalized use of medication can harm the social life of the individual, who tends to feel stigmatized by his or her health condition and by the fact of "taking controlled medication", which is often inefficient ${ }^{30}$.

However, the importance of psychopharmacology cannot be denied. Especially when associated with other therapeutic options, such as psychotherapy, occupational therapy, psychoeducation, social therapy, among others ${ }^{31}$. It is an efficient tool in the control of symptoms; decrease of seizure recurrence; increase in the quality of life, by allowing patients to be treated without the need for isolation so that they can participate directly in their treatment process $^{4}$

In this study, a total of 533 drugs were prescribed, which represents an average of 3.39 medicines per user, similar result was found by Andrade and Neta (2014) ${ }^{32}$. The concomitant use of different drugs may lead to negative interactions, causing a change in the therapeutic effect or an increase in the adverse effects of the associated drugs ${ }^{33}$. On the other hand, they can bring therapeutic benefits in specific situations ${ }^{34}$. It is important to emphasize that the concomitant use of multiple medications is frequent in the context of mental health and is often necessary due to the complexity of the symptoms.

According to Law No. 9,787, of February 10th, 1999, every prescription of medicines, under the Brazilian System of Health $(B S H)$, must adopt the BCD or in its absence, the International 
Nonproprietary Names (INN) ${ }^{35}$. Thus, although most of the drugs in this study were prescribed by the BCD, the ideal would be that the result was $100 \%$ and not $83.2 \%$ as it was found (Table 2 ). The use of BCD avoids confusion in the identification of drugs and the purchase of drugs at higher prices ${ }^{36}$

The list of essential drugs is an important parameter for measuring the reality of drug acquisition, considering that medicines that are not on the essential drug lists are likely to be purchased or required through judicial proceedings ${ }^{37}$.

Some medicines like risperidone, olanzapine and topiramate are drugs of the specialized component of pharmaceutical care (SCPC), group 1B (medicines purchased by the States, but with transfer of financial resources from the Ministry of Health), 1A (medicines with centralized purchase by the Ministry of Health) and 2 (medicines for diseases with less complex treatment in relation to those listed in Group 1 and cases of refractoriness or intolerance to the first line of treatment), according to Ordinance 1554 of 2013 from the Ministry of Health. Its obtention is made through specific requirements ${ }^{38}$.

Regarding the route of administration, no work was found in PSC with verification of this variable. However, in a health center in the city of Lajeado-RS, Brazil, Laste and collaborators (2013) ${ }^{37}$ reported that the percentage of prescribed injectables was also $3 \%$. In Farias $(2007)^{39}$, the percentage was $1.1 \%$. Injectable medications require increased demand of employeesand bring greater discomfort in the application, especially in the context of mental health. In addition, they are more prone to the occurrence of adverse reactions.

While tablets are pharmaceutical forms of easy administration, easy handling and accurate in dosage. However, the partitioning of tablets is often requested by some prescribers in order to obtain a dose not yet available on the market or to reduce treatment $\operatorname{costs}^{40}$. However, the tablet being a unit dosage form, at the time of partition, can break or disintegrate, affecting the dosage of the drug (dose variation) and promoting drug instability which can be interpreted by patients as a quality deviation, interfering with the credibility of the product ${ }^{40-41}$

Antipsychotics were the most prevalent class of drugs in this study (Table 2). This result was expected, since the profile of users diagnosed with groups F20 to F29 was also high in this study. As in this study, Ballarin and collaborators $(2011)^{19}$ and Souza and collaborators $(2012)^{12}$ also observed the prevalence of antipsychotic drugs in their research.

\section{Conclusion}

Medicines are great allies in psychosocial treatment. In cases where drug therapy is commonly based on the use of multiple drugs, it is necessary to know about the medicines that are used. From the obtained results, it was observed that most of the drugs were prescribed based on the BDC, on the MRED, and were related to the diagnostic profile of the users, but a rational analysis of the prescriptions was not performed. This study found that women were responsible for the highest percentage of schizophrenia, schizotypal and delusional disorders, and affective mood disorders. Antipsychotics were the most prevalent class of drugs reported in this study, which may be due to the high profile of users diagnosed with groups F20 to F29.

\section{Funding sources}

This research did not receive funding from any institution or company.

\section{Collaborators}

TAS: conception, design, data collection, analysis and interpretation of data, preparation of the article. ASF: guidance on preparation, data collection. SEAA: guidance on preparation, data collection. ASF: analysis and interpretation of data and critical review of the manuscript. EOS: critical review of the manuscript. MAA: critical review of the manuscript. PJRN: review of collected data and critical review of the manuscript. RMFS: conception, design, preparation guidance, critical review relevant to the content and final approval of the version to be published. The authors were responsible for all aspects of the work in ensuring the accuracy and integrity of any part of the work.

\section{Acknowledgments}

We thank the PSC where the study took place for institutional support and all employees for their contribution during the data collection period.

\section{Conflict of interests statement}

The authors declare that there are no conflicts of interest regarding this article.

\section{References}

1. Onocko-Campos RT, Passos E, Palombini AL, et al. A gestão autônoma da medicação: uma intervenção analisadora de serviços em saúde mental. Ciência \& Saúde Coletiva. 2013; 18(10):2889-2898.

2. Goulart MSB, Durães F. A reforma e os hospitais psiquiátricos: histórias da desinstitucionalização. Psicologia \& Sociedade. 2010; 22(1):112-120.

3. Bellettini F, Gomes K.M. Perfil dos usuários do Centro de Atenção Psicossocial e do Programa de saúde mental no município de Orleans - SC. Cadernos Brasileiros de Saúde Mental. 2013; 5(12):161-175.

4. Zanella CG, Aguiar PM, Storpirtis S. Atuação do farmacêutico na dispensação de medicamentos em Centros de Atenção Psicossocial adulto no município de São Paulo, SP, Brasil. Ciência \& Saúde Coletiva. 2013; 20(2):325-332.

5. Brasil. Ministério da Saúde. Saúde mental no SUS: os centros de atenção psicossocial, 1a edição. Brasília: Editora MS; 2004.

6. Associação Brasileira de Psiquiatria (ABP). Diretrizes para um modelo de assistência integral em saúde mental no Brasil, 1aㅡ edição. Rio de Janeiro: ABP; 2006.

7. Silva JC, Dullius CE, Castoldi DR. A relação entre o uso de psicofármacos e o processo de psicoterapia na infância. Revista de Psicologia. 2011; 2(1):86-94.

8. Cardoso L, Galera SAF. Doentes mentais e seu perfil de adesão ao tratamento psicofarmacológico. Revista da escola de enfermagem da USP. 2009; 43(1):161-167.

9. Sousa M. Perfil dos utilizadores de psicofármacos na unidade 
de Saúde familiar de Canelas. Revista Portuguesa de Clínica Geral. 2007; 23:33-42.

10. Correia GAR, Gondim APS. Utilização de benzodiazepínicos e estratégias farmacêuticas em saúde mental. Saúde Debate. 2014; 38(101):393-398.

11. CastroCGSO, coordenador. Estudos deutilização de medicamentos: noções básicas, 1a edição. Rio de Janeiro: FIOCRUZ; 2000

12. Souza TT, Silva WB, Quintans JSS, et al. Drug utilization research in a primary mental health service in Northeast of Brazil. Revista Portuguesa de Saúde pública. 2012, 30(1):55-61.

13. Miot HA. Tamanho da amostra em estudos clínicos e experimentais. J Vas Bras. 2011, 10(4):375-378.

14. Paula CTC. Perfil epidemiológico dos usuários de um centro de atenção. Psicossocial na cidade de recife. Cadernos Brasileiros de Saúde Mental. 2007; 2(4):94-105.

15. Kantorski LP, Jardim VMR, Porto $A R$, et al. Descrição de oferta e consumo dos psicofármacos em Centros de Atenção Psicossocial na Região Sul brasileira. Revista Escola Enfermagem da USP. 2011; 45(6):481-487.

16. Oliveira VF, Alves JS, Moraes ACS, et al. Caracterização de pacientes com transtornos mentais atendidos no centro de atenção psicossocial em São Francisco do Conde - Bahia. Revista de Ciências Médicas e Biológicas. 2014; 13(2):204-211.

17. Freitas AA, Souza RC. Caracterização clínica e sociodemográfica dos usuários de um Centro de atenção psicossocial (CAPS). Revista Baiana de Saúde Pública Miolo. 2010; 34(3):530-543.

18. Leal BM, Antoni C. Os Centros de Atenção Psicossocial (CAPS): estruturação, interdisciplinaridade e intersetorialidade. Aletheia. 2013; 1(40): 87-101.

19. Ballarin MLGS, Miranda IMS, Carvalho CM. Centro de Atenção Psicossocial do município de Campinas: estudo sobre o perfil sociodemográfico e clínico de seus usuários. Revista de Ciências Médicas. 2011; 20(3):59-67.

20. Mangualde AAS, Botelho CC, Soares MR, et al. Perfil epidemiológico dos pacientes atendidos em um Centro de Atenção Psicossocial. Mental. 2013; 10(19):235-248.

21. Brasil. Ministério da Saúde. Legislação em saúde mental: 1990-2004, 5a edição. Brasília: Editora MS; 2004

22. Andrade LHSG, Viana MC, Silveira CM. Epidemiologia dos transtornos psiquiátricos na mulher. Revista de Psiquiatria Clínica. 2006; 33(2):43-54

23. Fernandes $M R$, Lopes $\amalg$, Rocha MP, et al.Prescription for psychiatric patients in a brazilian public hospital: cross-sectional study. Rev Bras Farm Hosp Serv Saúde. 2019; 10(4):1-7.

24. Alves H, Kessier F, Ratto LRC. Comorbidade: uso de álcool e outros transtornos psiquiátricos. Revista Brasileira de Psiquiatria. 2004; 26(1):51-53.

25. Malbergier A, Oliveira JHP. Dependência de tabaco e comorbidade psiquiátrica. Revista de Psiquiatria Clínica. 2005; 32(5):276-282

26. Rodrigues MAP, Facchini LA, Lima MS. Modificações nos padrões de consumo de psicofármacos em localidade do Sul do Brasil. Revista de saúde pública. 2006; 40(1):107-114.

27. Ferrazza DA, Rocha LC, Luzio CA. Medicalização em um serviço público de saúde mental: um estudo sobre a prescrição de psicofármacos, Gerais: Revista Interinstitucional de Psicologia. 2013; 6(2):255-265

28. Xavier MS, Terra MG, Silva CT, et al. O significado da utilização de psicofármacos para indivíduos com transtorno mental em acompanhamento ambulatorial. Escola Anna Nery Revista de Enfermagem. 2014; 18(2):323-329.

29. Santos HC, Ribeiro RR, Ferrarini M, et al. Possíveis interações medicamentosas com psicotrópicos encontradas em pacientes da Zona Leste de São Paulo. Revista de Ciências Farmacêutica Básica Aplicada. 2009;30(3):285-289.

30. Ferreira ACZ. A complexa vivência do portador de transtorno mental no uso de psicofármacos [Dissertação]. Universidade Federal da Paraná, Curitiba, 2015

31. Vedana KGG, Miasso Al. The meaning of pharmacological treatment for schizophrenic patients. Revista Latino Americana de Enfermagem. 2014; 22(4):670-678.

32. Andrade KVF, Neta ZDB. Perfil farmacoepidemiológico das Interações medicamentosas potenciais em prescrições de psicofármacos Revista eletrônica de farmácia. 2014; 11(4):72-85.

33. BalenE, Giordani F, Cano MFF, etal. Interações medicamentosas potenciais entre medicamentos psicotrópicos dispensados. J. bras. psiquiatr. 2017, 66(3):172-177.

34. Brasil. Ministério da saúde. Uso racional de medicamentos: temas selecionados, 1a edição. Brasília: Editora MS; 2012.

35. Brasil. Ministério da Saúde. Agência Nacional de Vigilância Sanitária. Lei no 9.787 de 10 de fevereiro de 1999. Altera a Lei n. 6.360 de 23 de setembro de 1976, que dispõe sobre a vigilância sanitária, estabelece o medicamento genérico, dispõe sobre a utilização de nomes genéricos em produtos farmacêuticos e dá outras providências. Diário Oficial da União, Brasília, DF, 24 set 1999.

36. Souza JM, Vinholes ER, Trauthman SC, et al. Avaliação dos indicadores de prescrição e da demanda atendida de medicamentos no Sistema Único de Saúde de um município do Sul do Estado de Santa Catarina. Revista de Ciências Farmacêutica Básica Aplicada. 2012; 33(1):107-113.

37. Laste G, Torres ILS, Deitos A, et al. Análise de prescrições médicas dispensadas em farmácia no Sistema Único de saúde. Revista do Hospital de Clínicas de Porto Alegre. 2013; 33(1):15-25.

38. Brasil. Ministério da Saúde. Portaria no 1554 de 30 de julho de 2013 Dispõe sobre as regras de financiamento e execução do Componente Especializado da Assistência Farmacêutica no âmbito do Sistema Único de Saúde (SUS). Diário Oficial da União, Brasília, DF, 30 jul 2013.

39. Farias AD, Cardoso MAA, Medeiros ACD, et al. Indicadores de prescrição médica nas unidades básicas de Saúde da Família no município de Campina Grande, PB. Revista Brasileira de Epidemiologia. 2007; 10(2):149-156.

40. Ferreira AAA, Prates EC, Fernandes JPS, et al. Avaliação do efeito da partição de comprimidos de furosemida sobre a uniformidade da dose. Revista de Ciências Farmacêuticas Básica Aplicada. 2011; 32(1):47-53.

41. Conti MA, Adelino CC, Leite LB, et al. Partição de comprimidos: considerações sobre o uso apropriado. Boletim farmacoterapêutica. 2007; 22(4):1-6 